\title{
Correction to: Antibiotic resistance pattern and virulence genes content in avian pathogenic Escherichia coli (APEC) from broiler chickens in Chitwan, Nepal
}

\author{
Manita Subedi ${ }^{1}$, Rebanta Kumar Bhattarai ${ }^{2}$, Bhuminand Devkota ${ }^{1}$, Sarita Phuyal ${ }^{1}$ and Himal Luitel ${ }^{1 *}$
}

\section{Correction}

The original article [1] contains errors in author panels and their contributions, errors in both the Methodology and the Results sections, and errors with respect to funding sources. The affected sections of the manuscript and their respective regions of corrected text can be viewed ahead:

\section{Authorship}

The correct authors of the original article [1] can be viewed in the header of this manuscript.

\section{Methods}

Sample collections, bacterial isolation and identification

Fifty liver samples were collected from 50 colibacillosis suspected broiler chickens which were attended from May 2016 to January 2017 for routine diagnosis at National Avian Disease Investigation Laboratory (NADIL) and Veterinary Teaching Hospital, Agriculture and Forestry University, Rampur, Nepal.

\section{Detection of virulence genes}

Isolated $E$. coli strains were investigated for the presence of eleven virulence genes (iutA, iss, papC, iucD, tsh, irp-2, ompT, hlyF, iron, $c v a / c v i$, and astA) which are associated with colibacillosis. For the detection of virulence genes, genomic DNA was extracted from pure cultures of E. coli grown overnight in the MacConkey agar at $37^{\circ} \mathrm{C}$ by using the DNeasy Blood and Tissue Kit (Qiagen, catalogue no. 69506). The quality of genomic DNA was checked by gel electrophoresis and measuring absorbance at A260/A280 and A260/A230 ratios using

\footnotetext{
* Correspondence: hluitel@afu.edu.np

${ }^{1}$ Center for Biotechnology, Agriculture and Forestry University, Rampur,

Chitwan, Nepal

Full list of author information is available at the end of the article
}

the Quawell UV spectrophotometer (Q3000, USA). The conventional PCR was used to amplify the virulence genes. The primers used for amplification were those described previously (Table 1) $[17,18]$. The PCR was performed in $25 \mu \mathrm{L}$ volume containing $12.5 \mu \mathrm{L}$ Hot start Taq 2X master mix (BioLab Inc., New England), $1 \mu \mathrm{L}$ each primer $(1 \mu \mathrm{M}$ concentration), $2 \mu \mathrm{L}(20 \mathrm{ng} / \mu \mathrm{L}$ optimized by dilution) DNA template, and $8.5 \mu \mathrm{L} \mathrm{nu-}$ clease free water. The PCR amplifications were conducted in T100 Thermal Cycler (Bio-Rad, USA) and the cycling conditions were identical for all the samples as follows:

Table 1 Primer sets for detection of target virulence genes from avian pathogenic Escherichia coli (APEC) isolates

\begin{tabular}{|c|c|c|}
\hline Genes & Primer Sequence $\left(5^{\prime}-3^{\prime}\right)$ & $\overline{\text { Amplicon size (bp) }}$ \\
\hline iutA & $\begin{array}{l}\text { F: GGCTGGACATCATGGGAACTGG } \\
\text { R: CGTCGGGAACGGGTAGAATCG }\end{array}$ & 302 \\
\hline iss & $\begin{array}{l}\text { F: CAGCAACCCGAACCACTTGATG } \\
\text { R: AGCATTGCCAGAGCGGCAGAA }\end{array}$ & 309 \\
\hline papC & $\begin{array}{l}\text { F: TGATATCACGCAGTCAGTAGC } \\
\text { R: CCGGCCATATTCACATAA }\end{array}$ & 501 \\
\hline iucD & $\begin{array}{l}\text { F: ACAAAAAGTTCTATCGCTTCC } \\
\text { R: CCTGATCCAGATGATGCTC }\end{array}$ & 714 \\
\hline tsh & $\begin{array}{l}\text { F: ACTATTCTCTGCAGGAAGTC } \\
\text { R: CTTCCGATGTTCTGAACGT }\end{array}$ & 824 \\
\hline irp-2 & $\begin{array}{l}\text { F: AAGGATTCGCTGTTACCGGAC } \\
\text { R: AACTCCTGATACAGGTGGC }\end{array}$ & 413 \\
\hline ompT & $\begin{array}{l}\text { F: TCATCCCGGAAGCCTCCCTCACTACTAT } \\
\text { R: TAGCGTTTGCTGCACTGGCTTCTGATAC }\end{array}$ & 496 \\
\hline hlyF & $\begin{array}{l}\text { F: GGCCACAGTCGTTTAGGGTGCTTACC } \\
\text { R: GGCGGTTAAGGCATTCCGATACTCAG }\end{array}$ & 450 \\
\hline iroN & $\begin{array}{l}\text { F: AATCCGGCAAAGAGACGAACCGCCT } \\
\text { R:GTTCGGGCAACCCCTGCTTTGACTTT }\end{array}$ & 533 \\
\hline $\mathrm{cva} / \mathrm{cvi}$ & $\begin{array}{l}\text { F: TGGTAGAATGTGCCAGAGCAAG } \\
\text { R: GAGCTGTTTGTAGCGAAGCC }\end{array}$ & 1181 \\
\hline astA & $\begin{array}{l}\text { F: TGCCATCAACACAGTATATCC } \\
\text { R: TCAGGTCGCGAGTGACGGC }\end{array}$ & 116 \\
\hline
\end{tabular}


$94{ }^{\circ} \mathrm{C}$ for $4 \mathrm{~min}$; 35 cycles of $30 \mathrm{~s}$ at $94{ }^{\circ} \mathrm{C}, 1 \mathrm{~min}$ at $60{ }^{\circ} \mathrm{C}$, and $2 \mathrm{~min}$ at $68{ }^{\circ} \mathrm{C}$; and $72{ }^{\circ} \mathrm{C}$ for $7 \mathrm{~min}$. The amplicons were analyzed by agarose gel electrophoresis with $1.5 \%$ agarose gel (Sigma-Aldrich, A4718) prepared in 1× TBE buffer (Thermo Fisher Scientific, B52). All the PCR products were stained with ethidium bromide. After electrophoresis, the bands were visualized and photographed under UV light. The amplified product was considered to contain virulence gene if it produced band of the expected size.

\section{Results}

A total of $50 \mathrm{E}$. coli strains were isolated from 50 liver swab samples of colibacillosis suspected broiler chickens. The antibiogram profile of $E$. coli isolates showed highest resistance to ampicillin (98\%) and least resistance to amikacin (16\%) (Fig. 1). Out of $50 \mathrm{E}$. coli isolates, 47 (94\%) isolates were resistant to three or more antibiotics. The MAR index analysis showed $94 \%$ of $E$. coli isolates had MAR index value of $>0.2$ and $6 \%$ had MAR index value of $\leq 0.2$. The proportions of isolates with the MAR index values of $0.3,0.4,0.5$, and 0.6 were $12 \% 20 \%, 22 \%$, and $20 \%$, respectively. There was no significant association of prevalence of antibiotic resistant strains with the type of $E$. coli strains $(P>0.05)$.

Based on the genetic criteria for the pathogenicity, isolates containing at least five virulence genes were considered as the APEC strains and isolates containing less than five virulence genes were considered as the avian nonpathogenic Escherichia coli (non-APEC) strains. Out of 50 E. coli isolates, 45 (90\%) isolates were found to be APEC strains and $5(10 \%)$ isolates were found to be non-APEC strains (Table 2). Among $50 \mathrm{E}$. coli isolates, 7 isolates contained all the eleven virulence genes, 14 isolates contained ten virulence genes, 15 isolates contained nine virulence genes, 5 isolates contained eight virulence genes, 2 isolates contained seven virulence genes, 2 isolates contained five virulence genes, 4 isolates contained 4 virulence genes, and 1 isolates contained 3 virulence genes.

\section{Declarations}

\section{Funding}

This work was supported financially by Directorate of Research and Extension (DOREX), Agriculture and Forestry University, Rampur, Chitwan, Nepal and National Agricultural Research Development Fund (NARDEF), Nepal.

\section{Authors' Contributions}

$\mathrm{HL}, \mathrm{BD}$ and RKB conceived the concept, design, and supervised this study. MS and SP performed experimental work. MS, RKB and HL analyzed data and prepared the final draft of the manuscript. All authors read and approved the final manuscript.

\section{References}

Reference [24] in the original article mistakenly omits some author details and as such, the correct presentation of this reference can be seen in reference [2] of this Correction article.

\section{Author details}

${ }^{1}$ Center for Biotechnology, Agriculture and Forestry University, Rampur, Chitwan, Nepal. ${ }^{2}$ Department of Veterinary Microbiology and Parasitology, Agriculture and Forestry University, Rampur, Chitwan, Nepal.

Received: 5 April 2018 Accepted: 13 April 2018

Published online: 22 May 2018

\section{References}

1. Subedi M, et al. Antibiotic resistance pattern and virulence genes content in avian pathogenic Escherichia coli (APEC) from broiler chickens in Chitwan, Nepal. BMC Vet Res. 2018;14:113.

2. Parul S, Bist B, Sharma B, Jain U. Virulence associated factors and antibiotic sensitivity pattern of Escherichiacoli isolated from cattle and soil. Vet World 2014;7(5):369-72.

Ready to submit your research? Choose BMC and benefit from:

- fast, convenient online submission

- thorough peer review by experienced researchers in your field

- rapid publication on acceptance

- support for research data, including large and complex data types

- gold Open Access which fosters wider collaboration and increased citations

- maximum visibility for your research: over $100 \mathrm{M}$ website views per year

At BMC, research is always in progress.

Learn more biomedcentral.com/submissions 